\title{
Dung feeding in hydrophilid, geotrupid and scarabaeid beetles: Examples of parallel evolution
}

\author{
PETER HOLTER \\ Department of Terrestrial Ecology, Institute of Biology, University of Copenhagen, Universitetsparken 15, \\ DK-2100 Copenhagen Ø, Denmark; e-mail: pholter@bi.ku.dk
}

Key words. Dung beetles, Hydrophilidae, Geotrupidae, Scarabaeidae, feeding habits, particle feeding, mouthparts, evolution

\begin{abstract}
The maximum size of ingested ball-shaped particles was determined in three species of adult dung feeding beetle: Anoplotrupes (Geotrupes) stercorosus and Geotrupes spiniger (Geotrupidae, Geotrupinae) and Sphaeridium lunatum (Hydrophilidae, Sphaeridiinae). Maximum diameters were $40-65 \mu \mathrm{m}, 60-75 \mu \mathrm{m}$ and $16-19 \mu \mathrm{m}$ in A. stercorosus, G. spiniger and $S$. lunatum, respectively, and it was concluded that these beetles feed in the same way as found in previous studies on coprophagous scarabaeids (Scarabaeinae and Aphodiinae). Coarse particles, mainly indigestible plant fragments, are rejected by an unknown filtering mechanism, and only very small particles are actually ingested. The two geotrupids, however, tolerate somewhat larger particles than do scarabaeines of similar size. This may reflect a lower degree of specialisation towards dung feeding in the geotrupids than in the scarabaeines. In several ways, the mouthparts of the coprophagous Scarabaeidae, Geotrupidae and Hydrophilidae show essentially the same morphological modifications that must be adaptations for dung feeding. For the hydrophilid (Sphaeridium), such modifications are described for the first time. They include asymmetric mandibular molars (right convex, left concave), fitting exactly into each other, with highly specialised surfaces that may concentrate the food prior to ingestion by squeezing fluid out of it. Other examples are the conjunctives (scarabaeids and geotrupids) or similar structures (the hydrophilid) and the large, hairy, pad-like distal lobes of the maxillar galeae. Provided that current views on the evolutionary history of these beetles are correct, dung feeding has arisen independently in the Scarabaeidae, Geotrupidae and Hydrophilidae. If so, the feeding on very small particles and the concomitant modifications of mouthparts in these three groups must be results of parallel evolution.
\end{abstract}

\section{INTRODUCTION}

Dung of mammalian herbivores is the main food of scarabaeid beetles and larvae belonging to the subfamily Scarabaeinae and the large tribe Aphodiini within the subfamily Aphodiinae (Halffter \& Edmonds, 1982; Cambefort, 1991; Scholtz \& Chown, 1995). Members of the other 11 subfamilies within the Scarabaeidae recognised by Lawrence \& Newton (1995) do not feed on dung. In the two coprophagous groups, the adult beetles ingest only minute particles of dung [2-50 $\mu \mathrm{m}$ maximum diameter in the species studied so far (Holter, 2000; Holter et al., 2002)]. Larger dung particles are rejected by the highly specialised mouthparts after a filtration process that remains little understood. The material to be eaten is thought to be concentrated by elimination of superfluous water, but not comminuted, on the strongly modified molar surfaces of the mandibles. Further details are given by Holter (2000) and Holter et al. (2002).

But there are other dung feeding beetles within the superfamily Scarabaeoidea. In particular, many members of the Holarctic subfamily Geotrupinae within the family Geotrupidae are, partly or wholly, coprophagous (e.g. Halffter \& Edmonds, 1982; Cambefort, 1991; Scholtz \& Chown 1995). To complete the list, geotrupid dung feeders include the subfamily Taurocerastinae [placed within the Geotrupinae by Lawrence \& Newton (1995)], comprising three Neotropical species (Zunino, 1984). Although mammalian dung may seem a rather special food resource, adult beetles that feed on it are not entirely restricted to the Scarabaeoidea (Hanski, 1987; Hanski \&
Cambefort, 1991). The best known examples may be the genus Sphaeridium and probably several species in the genus Cercyon, belonging to the mostly terrestrial subfamily Sphaeridiinae within the otherwise, and presumably originally, aquatic (e.g. Hansen, 1991, 1997; Beutel, 1994; Archangelsky, 1999) family Hydrophilidae (superfamily Hydrophiloidea). In these coprophilous hydrophilids, however, the larvae are predators, whereas both adults and larvae of most scarabaeoid dung beetles are coprophagous.

Various aspects of feeding, including details of mouthpart morphology and functioning, have been studied in adult coprophagous scarabaeids by several workers (e.g. Madle, 1934; Miller, 1961; Miller et al., 1961; Hata \& Edmonds, 1983; Edwards, 1991; Holter, 2000; Holter et al., 2002). In contrast, little is known about the feeding mechanism employed by adult, coprophagous geotrupids and hydrophilids. How do they utilise this unique form of detritus that - although always patchily distributed - may locally occur in abundance? Is their feeding also restricted to small particles (as in scarabaeines and aphodiines), and if so, how small are these particles? Are the mouthparts modified for dung feeding in a way similar to that found in Scarabaeinae and Aphodiini? If so, how many times are such modifications likely to have evolved? Based on a study of two geotrupid and one hydrophilid species, combined with existing data on dung feeding scarabaeids, these questions are addressed in the present paper. 
TABLE 1. Taxonomic affiliation, mean body weight and microhabitat (dung type) of the experimental beetles. Nomenclature according to Baraud (1992) (geotrupids) and Hansen (1987, 1991) (hydrophilid). Mean weights are based on 30,33 and 17 individuals in G. spiniger, A. stercorosus and S. lunatum, respectively.

\begin{tabular}{llll}
\hline Species & $\begin{array}{l}\text { Family, } \\
\text { subfamily, } \\
\text { tribe }\end{array}$ & Mean fresh weight $\pm \mathrm{SE}$ & Collected in \\
\hline $\begin{array}{l}\text { Geotrupes spiniger Marsham } \\
\text { Anoplotrupes (Geotrupes) stercorosus (Scriba) }\end{array}$ & $\begin{array}{l}\text { Geotrupidae, } \\
\text { Geotrupinae, } \\
\text { Geotrupini }\end{array}$ & $1.10 \mathrm{~g} \pm 0.031$ & $\begin{array}{l}\text { Cattle dung } \\
\text { Sphaeridium lunatum Fabricius }\end{array}$ \\
& $\begin{array}{l}\text { Hydrophilidae, } \\
\text { Sphaeridiinae, } \\
\text { Sphaeridiini }\end{array}$ & $0.37 \mathrm{~g} \pm 0.018$ & Cattle dung \\
\hline
\end{tabular}

\section{MATERIAL AND METHODS}

Table 1 summarises some information on the experimental animals. G. spiniger is widely distributed in Europe (e.g. Horion, 1958) and has been successfully introduced at various locations in south-eastern Australia (Tyndale-Biscoe, 1990). The beetles used in the present study were collected in a cattlegrazed pasture near Braidwood $\left(35^{\circ} 27^{\prime} \mathrm{S}, 149^{\circ} 49^{\prime} \mathrm{E}\right)$, New South Wales. They were tested at CSIRO Entomology, Canberra. The other species were collected near Hillerød $\left(55^{\circ} 56^{\prime} \mathrm{N}\right.$, $\left.12^{\circ} 22^{\prime} \mathrm{E}\right) \mathrm{NW}$ of Copenhagen: A. stercorosus from the wood Freerslev Hegn, and $S$. lunatum from permanent pasture (Østrupgård). Laboratory work on both species was done at the University of Copenhagen.

The details of the method used for measuring the size of particles ingested by the beetles are described and discussed by Holter (2000) and Holter et al. (2002). Briefly, small latex or glass balls of two different, known diameters were mixed evenly into fresh cattle or sheep dung and fed to beetles that had been starved for 2-3 days (in moist soil at about $20^{\circ} \mathrm{C}$ ) prior to feeding. Ball sizes ranged from $5-83 \mu \mathrm{m}$ in diameter. The ratio of the different-sized beads in the feeding mixture was determined from three random subsamples. After about 45 min of feeding at room temperature in darkness, each beetle was killed by immersion in boiling water, dried with paper towelling, weighed and dissected. A sample of the gut contents was extracted, placed in a drop of glycerol and water $(1: 1)$ on a microscope slide and covered with a cover slip. Balls were counted at 100-400 $\times$ magnification, and samples with $<50$ balls of the most abundant size category were discarded. If possible, counting of both particle sizes continued until at least 200 balls of the most abundant category had been scored. For all species, acceptable gut samples for each combination of bead sizes tested were obtained from at least five beetles.
The rather variable counts obtained from the gut samples were standardised in the following way. Based on the number of small balls counted in a sample, the expected corresponding number of large balls could be calculated, assuming that the two ball sizes were present in the same proportion as in the original food mixture. The actual count of large balls divided by the expected number, the ratio $\beta$ (usually expressed as a percentage), was then used as the standardised count (cf. Holter, 2000). $\beta=100 \%$ means that large and small balls occurred in identical proportions in gut samples and in the original dung mixture, which implies uninhibited ingestion of both sizes. $\beta<$ $100 \%$ indicates that the filter restricted the passage of the larger balls compared to that of the small ones. Moreover, a $\beta$-value relatively close to $100 \%$ suggests that the smaller balls passed the filter unimpeded, particularly if there was a considerable size difference between large and small balls. In accordance with Holter (2000) and Holter et al. (2002), the maximum size of ingested particles is defined as the diameter of a ball with a $5 \%$ chance of passing the mouthpart filter and being ingested.

Maxillae and mandibles of the three species were studied using a JEOL JSM-6335F field emission scanning electron microscope.

\section{RESULTS}

\section{Feeding experiments}

The $\beta$-values (see Material and Methods) resulting from the feeding trials are presented in Table 2. In size combinations where the small balls in dung collected by the mouthparts had a $100 \%$ chance of passing the filter and being ingested, $\beta$ is simply the probability of the large balls being eaten. In other cases, a correction is necessary to get that probability. In G. spiniger, for example, the

TABLE 2. Results of the feeding experiments. See text (Material and Methods, penultimate paragraph) for explanation of $\beta$-values.

\begin{tabular}{|c|c|c|c|c|}
\hline Species & Combination of ball sizes $(\mu \mathrm{m})$ & Mean $\beta$-value $(\%) \pm \mathrm{SE}$ & Range of $\beta$-values (\%) & Number of beetles tested \\
\hline \multirow[t]{4}{*}{ Geotrupes spiniger } & $10 / 25$ & $79.0 \pm 3.78$ & $67.0-89.0$ & 6 \\
\hline & $10 / 43$ & $46.2 \pm 7.30$ & $22.5-69.7$ & 7 \\
\hline & $25 / 63$ & $12.4 \pm 3.24$ & $2.26-27.3$ & 8 \\
\hline & $43 / 83$ & $7.90 \pm 2.09$ & $0-13.1$ & 7 \\
\hline \multirow[t]{4}{*}{ Anoplotrupes stercorosus } & $5 / 10$ & 100 & - & 8 \\
\hline & $10 / 25$ & $58.1 \pm 8.90$ & $23.6-87.6$ & 8 \\
\hline & $10 / 43$ & $21.0 \pm 6.86$ & $0.00-52.5$ & 8 \\
\hline & $25 / 63$ & $2.19 \pm 0.77$ & $0.00-7.24$ & 9 \\
\hline \multirow[t]{3}{*}{ Sphaeridium lunatum } & $5 / 10$ & $79.8 \pm 2.38$ & $75.3-87.8$ & 5 \\
\hline & $10 / 18$ & $8.73 \pm 2.15$ & $2.91-18.4$ & 7 \\
\hline & $10 / 20$ & $2.51 \pm 0.50$ & $1.48-4.27$ & 5 \\
\hline
\end{tabular}


TABle 3. Probabilities of passing the mouthpart filter (i.e. of being ingested) for balls of specified diameters. Values are based on data in Table 2, further explanation in text. Estimated maximum diameters of ingested particles are also given.

\begin{tabular}{|c|c|c|c|c|}
\hline \multirow{2}{*}{$\begin{array}{l}\text { Species } \\
\text { Geotrupes spiniger }\end{array}$} & \multicolumn{3}{|c|}{$\begin{array}{l}\text { Ball diameters and probabilities of ingestion; } \\
\text { mean probabilities and ranges (in brackets) }\end{array}$} & \multirow{2}{*}{$\begin{array}{l}\text { Estimated maximum diameter of } \\
\text { ingested particles } \\
60-90 \mu \mathrm{m}\end{array}$} \\
\hline & $\begin{array}{l}43 \mu \mathrm{m} \\
46.2 \% \\
(22.5-69.7 \%)\end{array}$ & $\begin{array}{l}63 \mu \mathrm{m} \\
9.80 \% \\
(1.51-24.3 \%)\end{array}$ & $\begin{array}{l}83 \mu \mathrm{m} \\
3.65 \% \\
(0-9.13 \%)\end{array}$ & \\
\hline $\begin{array}{l}\text { Anoplotrupes } \\
\text { stercorosus }\end{array}$ & $\begin{array}{l}25 \mu \mathrm{m} \\
58.1 \% \\
(23.6-87.6 \%)\end{array}$ & $\begin{array}{l}43 \mu \mathrm{m} \\
21.0 \% \\
(0.00-52.5 \%)\end{array}$ & $\begin{array}{l}63 \mu \mathrm{m} \\
1.27 \% \\
(0.00-6.34 \%)\end{array}$ & $40-65 \mu \mathrm{m}$ \\
\hline Sphaeridium lunatum & $\begin{array}{l}10 \mu \mathrm{m} \\
79.8 \% \\
(75.3-87.8 \%)\end{array}$ & $\begin{array}{l}18 \mu \mathrm{m} \\
6.97 \% \\
(2.19-16.2 \%)\end{array}$ & $\begin{array}{l}20 \mu \mathrm{m} \\
2.00 \% \\
(1.11-3.75 \%)\end{array}$ & $16-19 \mu \mathrm{m}$ \\
\hline
\end{tabular}

mean $\beta$ for the $10 \mu \mathrm{m} / 25 \mu \mathrm{m}$ combination was $79 \%$. Considering this relatively high value, it seems safe to assume that the $10 \mu \mathrm{m}$-particles had a $100 \%$ chance of being ingested, and so the mean probability of ingestion for a $25 \mu \mathrm{m}$-ball was $79 \%$. Turning to the testing of 63 $\mu \mathrm{m}$-balls, these large particles made the samples too thick for proper counting of $10 \mu \mathrm{m}$-balls. Consequently, the 63 $\mu \mathrm{m}$-balls had to be tested against $25 \mu \mathrm{m}$-balls that were easier to count. Hence, to estimate the mean probability of ingestion for a $63 \mu \mathrm{m}$-ball, the $\beta$-value $(12.4 \%)$ must be multiplied by that of the $25 \mu \mathrm{m}$-balls ( $79 \%$ or 0.79 ), which yields $9.8 \%$. Similarly, the lower limit of the range is estimated by multiplying the lower $\beta$-value $(2.26 \%)$ by the corresponding $\beta$-value from the $10 \mu \mathrm{m} / 25 \mu \mathrm{m}$ combination (0.67), which yields $1.51 \%$. The upper limit is estimated in the same way. Table 3 presents, for each species, the probabilities of ingestion for the three largest particle sizes tested. From these values, the maximum diameter of ingested particles, i.e. the size with a $5 \%$ chance of passing the mouthpart filter, was also estimated.

Whereas the maximum particle diameter in S. lunatum (16-19 $\mu \mathrm{m})$ seemed to be rather sharply defined, definition of the upper size limit for ingestion is much less constrained in the two geotrupids (e. g. 40-65 $\mu \mathrm{m}$ in A. stercorosus). Was this intraspecific variation related to corresponding variations in body size? To test this, four correlations $(n=6)$ between individual body weight $(\log$ transformed) and $\beta$ (arcsin-square root transformed) were calculated for $G$. spiniger (all ball size combinations) and three for A. stercorosus (10/25, 10/43 and 25/63 $\mu \mathrm{m})$. None of these correlations was significant, with r-values of -0.11 to 0.43 and P-values in the range 0.25 to 0.93 . Hence, a strong, intraspecific correlation between $\beta$-value and body size was not indicated.

\section{Mouthpart morphology}

A comprehensive morphological study is beyond the scope of the present paper, but a few relevant details of the mandibles in the geotrupids and of mandibles and maxillae in the hydrophilid are presented here. A general review of the terminology is given by Nel \& Scholtz (1990).

The mouthparts of the two geotrupids are very similar. The lateral part of the distal lobe (the incisor lobe or apicalis) in each mandible (Figs $1 \mathrm{a}-\mathrm{b}$ ) is completely sclero- tised, distally ending in two teeth $(\mathrm{t})$ that are more or less blunt according to the degree of wear. The median margin of the mandible proximal to the teeth is covered by a dense row of setae, the mesal brush (m) (e.g. Scholtz, 1990). A remarkable structure (co in Fig. 1b), the socalled conjunctive or conjunctivus (e.g. Hardenberg, 1907; Edmonds, 1972) is placed between the apicalis and the sclerotised basal part (the basalis) that bears the molar lobe. The conjunctive appears as a groove in the ventral surface, filled by parallel rows of thick adhering setae that lead from the basis of the mandible towards the mesal brush. In the conjunctive zone the mandible is rather thin and presumably more flexible than elsewhere (Miller, 1961; Edmonds, 1972). The asymmetrical molar surfaces (mo), convex in the right and concave in the left mandible (Figs 1a-b), fit exactly into each other. A close-up (Fig. 1c) shows that these surfaces consist of tightly packed transverse ridges that have tiny (about $2 \mu \mathrm{m}$ diameter) holes in their periphery.

The distal part of the maxillar galea in the two geotrupids [not shown here but illustrated for A. stercorosus in Nel \& Scholtz (1990) and for a few other coprophagous geotrupids in Hardenberg (1907) and Bürgis (1982)] are rather large, pad-like hairy structures, completely covered by setae with small apical hooks. The distal part of the lacinia is similar, but smaller.

In many ways, the mandibles of the hydrophilid $S$. lunatum (Figs 2a-d) resemble those of the geotrupids. Their lateral part is completely sclerotised with a pointed apical tooth $(\mathrm{t})$, the median margin proximal to this tooth being covered by a dense, mesal brush (m). Moreover, the molar surfaces (mo) are asymmetrical, concave in the left and convex in the right mandible - and fit exactly into each other. They consist of tightly packed, transverse ridges (Figs $2 \mathrm{c}-\mathrm{d}$ ). In each ridge there are minute, elongate holes (about $0.5 \times 1 \mu \mathrm{m}$ ) between the bases of lateral lobes with triangular apexes. These triangular structures fit into those of the adjacent ridges (Fig. 2d). Ventrally on the mandibles, oblique, parallel rows of dense, short setae ( $\mathrm{s}$ in Figs $2 \mathrm{a}-\mathrm{b}$ ) lead from the basis to the lower end of the mesal brush.

In the maxillae, the distal part of the galea $(\mathrm{g})$ is padlike and covered by hooked setae (Fig. 3), just like the galea of a scarabaeoid dung beetle. The distal part of the lacinia (1) is also covered by setae, but this lobe is considerably less prominent than that of the galea. 


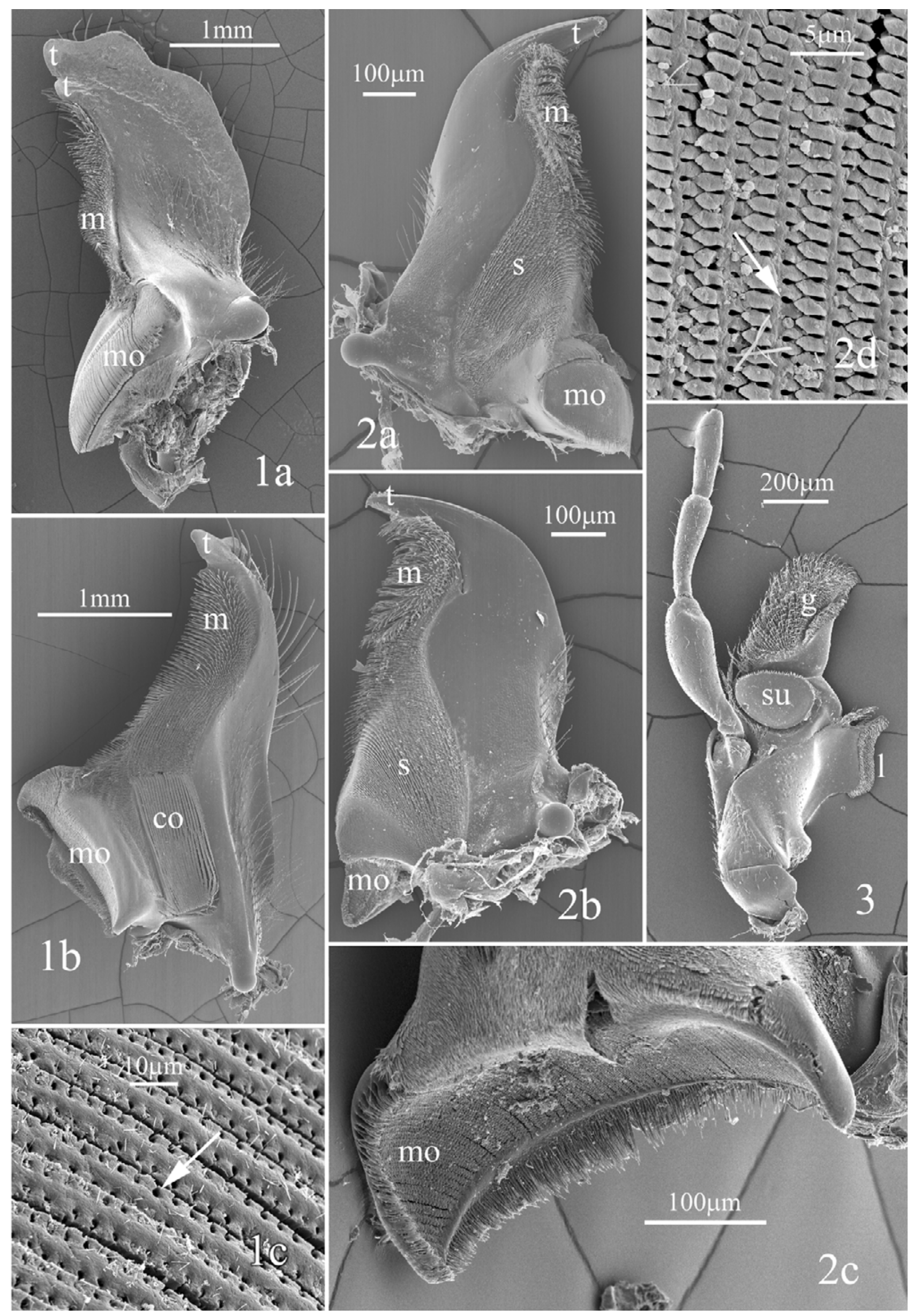




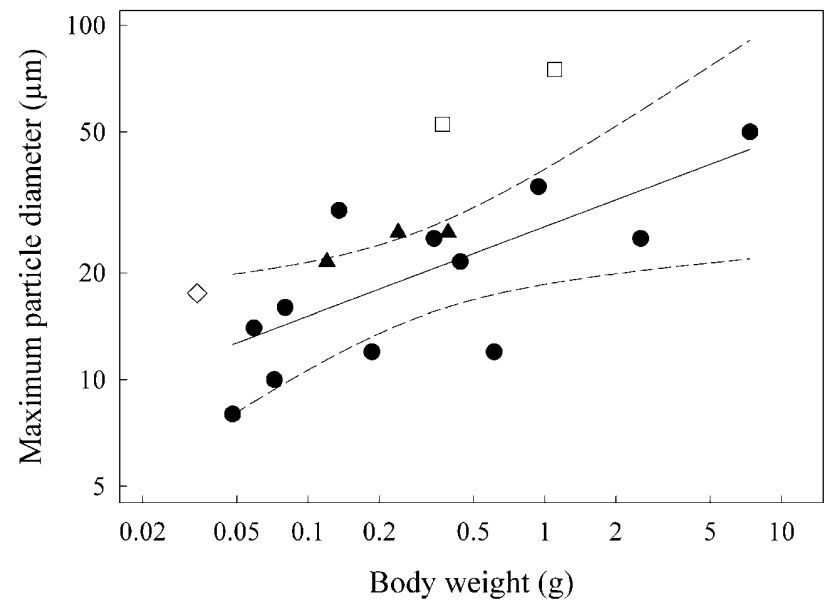

Fig. 4. Maximum diameter of ingested particles (midpoint of estimated range) in relation to mean fresh body weight for 18 species of dung feeding beetles. Logarithmic scales on both axes. Filled symbols: tunnelling (circles) and endocoprid (i.e. feeding and breeding in the dung pat itself) (triangles) Scarabaeinae (data from Holter et al., 2002). Empty symbols: geotrupids (squares) and hydrophilid (diamond). Solid and dotted lines: regression line and $99 \%$ confidence limits for the scarabaeines (i.e. all filled symbols).

\section{DISCUSSION}

\section{Geotrupidae (Geotrupes and Anoplotrupes)}

Maximum diameters of ingested particles in Geotrupes spiniger and Anoplotrupes stercorosus are about 60-90 and $40-65 \mu \mathrm{m}$, respectively (Table 3 ), and - in agreement with earlier findings for tunnelling and endocoprid scarabaeines (Holter et al., 2002) - there is no clear, intraspecific correlation between body weight and size of the particles that are eaten. Thus, by restricting their ingestion to small particles, these two geotrupids seem to feed in the same way as the coprophagous scarabaeids (cf. Holter, 2000; Holter et al. 2002). Coarse material, i.e. indigestible plant fragments consisting mainly of lignocellulose, is rejected, and only fine particles, including high-quality food such as bacteria and dead epithelial cells from the herbivore's gut, are ingested. Even so, Fig. 4 shows that the geotrupids ingest considerably larger particles than do scarabaeine tunnellers and endocoprids of similar size. In fact, the largest particles eaten by the geotrupid A. stercorosus, which weighs $0.37 \mathrm{~g}$, are slightly bigger than those accepted by the scarabaeine Heliocopris japetus Klug weighing 20 times as much (Holter et al., 2002). The relatively large food particles tolerated by adult Geotrupinae may reflect a lower degree of specialisation towards dung feeding compared to the
Scarabaeinae. Although Halffter \& Edmonds (1982) claimed that the Geotrupini (the tribe containing most of the Geotrupinae) are almost exclusively coprophagous, adult beetles of many species accept, or sometimes even prefer, several other kinds of food. In some species within the large, flightless genus Thorectes, for example, the adults seem to feed on various kinds of decaying organic matter, such as over-ripe fruit or carrion, but probably not dung (Palestrini \& Zunino, 1985). Even if they include coprophagy, such diverse feeding habits may necessitate ingestion of relatively large particles. If this were not the case, it could be difficult to extract sufficient amounts of food from substrates with a lower percentage of extremely small particles than that occurring in dung (cf. Holter, 2000; Holter et al., 2002).

As to the geotrupids studied here, adults of the forestliving A. stercorosus are strongly attracted to fresh dung, e.g. of horse, and feed either in the dung heap itself or, more commonly, in small stores of dung buried a few $\mathrm{cm}$ into the ground below the pat (Teichert, 1956). But beetles are also found - apparently feeding - in other substrates such as carrion or rotting mushrooms (e.g. Horion, 1958; Kühne, 1995; Holter, P., pers. obs.). Moreover, food stores for the larvae usually (always?) consist of various kinds of decaying organic matter other than dung (Rembiałkowska, 1982). Thus, although dung is readily eaten by adult $A$. stercorosus, this species may be able to subsist, breeding included, on a variety of other substrates. By contrast, both adults and larvae of $G$. spiniger are genuine dung feeders, living in open pastureland and utilising both horse and cattle dung (Kühne, 1995, and references therein).

Because the mandibular incisor lobe (the apicalis) in geotrupines (Figs 1a-b) is partly sclerotised (contrary to the completely soft apicalis in scarabaeines), the geotrupine mandibles have been characterised as approaching the biting type (Halffter \& Edmonds, 1982). The biting function, however, may be irrelevant in relation to feeding on fresh, soft dung. In the species studied here it is hard to envisage how the usually rather blunt terminal teeth might seize and cut the tough plant fragments which are the only larger particles in the dung. Moreover, any cutting by the more proximal median margin would be prevented by the mesal brush. On the other hand, it is conceivable that the teeth are used for penetration into other food items such as carrion. Also, the clypeus in these geotrupines is not nearly as wide and prominent as the shovel-shaped, corresponding structure in most scarabaeines which is a very important digging tool. However, a geotrupine "head shovel" could be formed by the clypeus in conjunction with the prominent, sclerotised

Fig. 1-3. 1 - Geotrupid mandibles. 1a: G. spiniger, right mandible, dorsal view. Distal teeth (t), mesal brush (m), molar (mo). 1b: G. spiniger (another individual than 1a), left mandible, ventral view. Conjunctive (co), other lettering as in 1a. 1c: A. stercorosus, close-up of molar surface with tightly packed transverse ridges. Arrow indicates a hole in the margin of a ridge. 2 - Mandibles of the hydrophilid S. lunatum. 2a: right mandible, ventral view. Apical tooth (t), mesal brush (m), conjunctive-like rows of setae (s), molar (mo). 2b: left mandible (another individual than 2a), ventral view. Lettering as in 2a. 2c: molar of a left mandible. Transverse ridges on the molar surface (mo) are distinguishable. $2 \mathrm{~d}$ : close-up of molar surface with tightly packed transverse ridges. Arrow indicates a hole in one of the ridges. 3 - Maxilla (ventral view) of a male $S$. lunatum. Galea (g), sucker disc-like structure characteristic of males (su), lacinia (1). 
parts of the mandibles, and so the latter may aid in digging tunnels through the soil as suggested by Bertin (1922). Apart from the partial sclerotisation of the incisor lobe, the mandibles and maxillae of the two geotrupids are quite similar to those of the dung feeding aphodiines (Madle, 1934) and scarabaeines (Miller, 1961; Halffter \& Edmonds, 1982; Hata \& Edmonds, 1983). Four important features (briefly described in the Results section) provide good examples of this resemblance.

(1) In both scarabaeines, aphodiines and geotrupines, the median mandibular margin bears a distinct mesal brush ( $\mathrm{m}$ in Figs 1a-b) distal to the molar lobe. Several authors (e.g. Madle, 1934; Hata \& Edmonds, 1983) suggest that this brush removes food from the hairy maxillar galeae that have collected it (c.f. (4) below).

(2) The highly specialised mandibular molars are similar in all dung feeding Scarabaeoidea, including geotrupids (Madle, 1934; Miller, 1961; Hata \& Edmonds, 1983). They are asymmetrical (left concave, right convex) and fit exactly into each other. The surfaces (cf. Fig. 1c) consist of tightly packed, transverse ridges with a more or less complex pattern of very fine fissures and/or holes leading to deeper channels between the bases of the ridges. Miller (1961) suggested that a grinding action of the molar surfaces (functioning "like a pair of opposed millstones") comminutes larger dung particles prior to ingestion and that the elaborate relief on the ridges aids in an efficient trituration of the material. This suggestion was adopted by several later authors, e.g. Halffter \& Matthews (1966), Halffter \& Edmonds (1982), Hata \& Edmonds (1983) and Cambefort (1991). However, recent experimental evidence (Holter, 2000; Holter et al., 2002) indicates that the molars of aphodiines and scarabaeines do not achieve any grinding. Considering their identical morphology, the molars of coprophagous geotrupids are not likely to do it either. What might then be the function of these remarkable structures? In this connection it should be remembered that fresh cattle dung from which all particles above e.g. $50 \mu \mathrm{m}$ diameter have been removed, i.e. about half of the dry matter in the unmodified dung, may contain at least $90 \%$ water. The same is true of most fresh sheep and horse dung (Holter, P., pers. obs.). A certain elimination of fluid prior to ingestion would therefore seem desirable, and Holter (2000) suggested that the food is concentrated by being squeezed between the molars. Superfluous fluid could then drain away through the tiny holes and fissures in and between the transverse ridges of the molar surfaces - and eventually be eliminated through the channels between the bases of these ridges.

(3) The mandibles of the dung feeding geotrupines have well-developed conjunctives (co in Fig 1b), apparently identical to those seen in scarabaeines and aphodiines. The presence of conjunctives in all coprophagous taxa [noted already by Hardenberg (1907)], and their absence in practically all other scarabaeoids (Nel \& Scholtz, 1990), suggest an essential function in dung feeding. According to Madle (1934), the conjunctive is a system of salivary channels ("Speichelkanäle"), adding saliva to the incoming food. The salivary glands feeding these channels are not documented by any illustrations in Madle's paper, nor is it clear why the presumably already wet and soft food would need to be mixed with saliva ("eingespeichelt") prior to ingestion. Miller (1961) hypothesised that the "flexible area of the mandible", i.e. the conjunctive, "cushions" the grinding action and permits independent movements of the molar lobes "while the mandibles are in the closed position". However, no such grinding is likely to take place (cf. (2) above), and so neither Madle's nor Miller's hypothesis seems entirely convincing. Clearly, the functional morphology of the conjunctive needs further study.

(4) Each maxillar galea bears a large, terminal pad-like lobe covered in hairs with small, apical hooks. This is characteristic of all scarabaeoid dung feeders, e.g. Bürgis, 1982 (Geotrupinae); Madle, 1934 (Aphodiinae); Miller, 1961; Halffter \& Edmonds, 1982 (Scarabaeinae). The lacinia has a smaller, but essentially similar, distal lobe. Madle (1934) suggested that these lobes, and particularly those of the galeae, collect food by licking movements, which has been generally accepted by later authors, including the present one.

Apart from the Glaresidae (considered a sister group to all other scarabaeoids), the scarabaeoid families are currently supposed to be divided into two main lineages that radiated from an early ancestor sometime during the Upper Jurassic. The Geotrupidae are in one of these lineages, the Scarabaeidae (including Aphodiinae and Scarabaeinae) in the other - and the common ancestor is believed not to have fed on dung (Scholtz \& Chown, 1995; Browne \& Scholtz, 1999; Krell, 2000; Scholtz, 2000, Philips et al., 2004). If these assumptions are correct, dung feeding based on selective ingestion of very small particles, accompanied by identical morphological specialisations of the mouthparts, must have evolved independently within each lineage, providing a remarkable example of parallel evolution within the Scarabaeoidea. It may even have happened once more. According to Krell (2000), the split between Aphodiinae and Scarabaeinae may have arisen already during the Upper Jurassic/Lower Cretaceous, and it is possible that the common ancestor of these subfamilies was not specialised for dung feeding (cf. Philips et al., 2004). Consequently, with our present knowledge, independent evolution within the Scarabaeidae of dung feeding in aphodiines and scarabaeines cannot be ruled out.

\section{Hydrophilidae (Sphaeridium)}

Adult Sphaeridium lunatum colonise completely fresh dung, cow pats in particular, and are probably exclusively coprophagous. As shown by the results, these beetles have also specialised in selective ingestion of tiny dung particles, while coarser material is rejected. The maximum diameter of particles eaten, 16-19 $\mu \mathrm{m}$, is within the same range as that found in dung feeding scarabaeine tunnellers of similar body size (Fig. 4). The evolution of this way of feeding in Sphaeridium has resulted in several modifications of the mouthparts that are similar to those seen in coprophagous scarabaeoids 
but not in other, non-coprophagous hydrophilids (Hansen, 1991). In the maxillae, for example, the galeae have large, distal lobes (Fig. 3) covered by hairs with apical hooks. By analogy with the scarabaeoids, food may be collected by these lobes and then possibly removed from them by the highly developed mesal brushes ( $m$ in Figs $2 a-b$ ) on the median margins of the mandibular incisor lobes. The most striking modification of the mandibles may be presented by the molars. Just like in the dung feeding scarabaeoids, they are asymmetrical, convex on the right mandible, concave on the left, and fitting exactly into each other. Moreover, the molar surfaces (Figs 2a-d) are covered by tightly packed transverse ridges with minute but distinct holes (for drainage of superfluous fluid?). The last structure to be mentioned here is the assemblage of oblique, parallel rows ( $\mathrm{s}$ in Figs $2 \mathrm{a}-\mathrm{b}$ ) of densely packed setae on the ventral surface of the mandible, in the transition zone between the molar and incisor lobe. This structure bears a certain resemblance to the scarabaeoid conjunctive, is placed in the same region on the mandible and might also have the same (unknown) function.

Like in the geotrupids, but not the scarabaeines and aphodiines, the lateral part of each incisor lobe is sclerotised, ending in a distal tooth. It is hard to imagine any function of these teeth related to feeding on soft, fresh dung, and alternative food sources for adult Sphaeridium, requiring pointed teeth, are not known. Since the beetles do not tunnel into hard soil, contrary to the geotrupids, use of the teeth for defensive purposes seems one of the few remaining possibilities.

According to current views (Hansen, 1997), Hydrophiloidea/Histeroidea and Scarabaeoidea are sister groups. These two lineages may have arisen already during the Jurassic or perhaps even late Triassic, and it seems very unlikely that their common ancestor was a specialised dung feeder. Moreover, the Sphaeridiinae is considered the most derived of the two subfamilies (e.g. Hansen, 1991) within the Hydrophilidae (sensu Hansen, 1991), and is the only one in which dung feeding is known. It follows that dung feeding in Sphaeridium, including modifications of the mouthparts that are quite similar to those in coprophagous scarabaeoids, is a result of an evolution parallel to the one that occurred independently within some scarabaeoid groups.

\section{CONCLUSIONS}

It could be argued that the most important ecophysiological problem for animals feeding on fresh dung of mammalian herbivores is that of extracting high-quality sources of energy and nitrogen from a watery suspension within a bulky matrix of indigestible plant fragments. The results presented here indicate that all adult beetles known to feed on fresh dung follow the same procedure. Coarse material (mostly indigestible plant fragments) is rejected through a filtration process carried out by the highly specialised mouthparts, and only very small particles are concentrated and then ingested. The adaptations of the mouthparts correlated with dung feeding are essentially the same in the Geotrupinae (Geotrupidae), the
Scarabaeinae and Aphodiinae (Scarabaeidae) and the Sphaeridiinae (Hydrophilidae). If current views on the evolutionary history of Geotrupidae, Scarabaeidae and Hydrophilidae are correct, dung feeding must have evolved independently in these groups, which means that the almost identical modifications of the mouthparts are parallelisms. Hence, given the evolutionary potential within the part of the suborder Polyphaga where the Scarabaeoidea and Hydrophiloidea belong (cf. Hansen, 1997), there seems to have been only one solution (for adult beetles) to the problem of efficient dung feeding.

ACKNOWLEDGEMENTS. Work in Australia was funded by the University of Copenhagen. I am grateful to K. Wardhaugh, CSIRO Entomology (Canberra), for invaluable practical help and for constructive criticism of the manuscript. Thanks are also due to J. Feehan of SoilCam (Canberra) for directing us to a population of Geotrupes spiniger. In Denmark, Frederiksborg State Forest District kindly provided access to a pasture at Østrupgård. Finally, thanks are due to B. Bisballe and D. Nash (Univ. of Copenhagen) for skilful assistance with scanning electron microscopy and processing of pictures and to an anonymous referee for valuable suggestions.

\section{REFERENCES}

Archangelsky M. 1999: Adaptations of immature stages of Sphaeridiinae (Staphyliniformia, Hydrophiloidea: Hydrophilidae) and state of knowledge of preimaginal Hydrophilidae. Coleopt. Bull. 53: 64-79.

BARAUD J. 1992: Faune de France. 78. Coléoptères Scarabaeoidea d'Europe. Société Linnéenne de Lyon, Lyon, 867 pp.

BERTIN L. 1922: L'adaptation des pièces buccales aux régimes alimentaires chez les Coléoptères Lamellicornes. Annls Soc. Linn. Lyon 69: 145-159.

Beutel R.G. 1994: Phylogenetic analysis of Hydrophiloidea based on characters of the head of adults and larvae. Koleopt. Rdsch. 64: 103-131.

Browne J. \& Scholtz C.H. 1999: A phylogeny of the families of Scarabaeoidea (Coleoptera). Syst. Entomol. 24: 51-84.

Bürgis H. 1982: Gourmets unter den Käfern: Die Kotfresser (Coprophaga). 1. Hartkotfresser vom Geotrupes-Typ. A. Lebensweise und Mundwerkzeuge des Stierkäfers. Mikrokosmos 71: 298-303.

CAMBEFORT Y. 1991: From saprophagy to coprophagy. In Hanski I. \& Cambefort Y. (eds): Dung Beetle Ecology. Princeton University Press, Princeton, New Jersey, pp. 22-35.

EDMONDS W.D. 1972: Comparative skeletal morphology, systematics and evolution of the phanaeine dung beetles (Coleoptera: Scarabaeidae). Kans. Univ. Sci. Bull. 69: 731-874.

EDWARDS P.B. 1991: Seasonal variation in the dung of African grazing mammals, and its consequences for coprophagous insects. Funct. Ecol. 5: 617-628.

Halffter G. \& Edmonds W.D. 1982: The Nesting Behavior of Dung Beetles (Scarabaeinae). An Ecological and Evolutive Approach. Instituto de Ecologia, Mexico, D.F., 176 pp.

Halffter G. \& Matthews E.G. 1966: The natural history of dung beetles of the subfamily Scarabaeinae (Coleoptera, Scarabaeidae). Folia Entomol. Mex. 12-14: 1-312.

HANSEN M. 1987: Fauna Entomologica Scandinavica. Vol. 18. The Hydrophiloidea (Coleoptera) of Fennoscandia and Denmark. E.J. Brill/Scandinavian Science Press, Leiden, Copenhagen, $254 \mathrm{pp}$. 
Hansen M. 1991: The hydrophiloid beetles. Phylogeny, classification and a revision of the genera (Coleoptera, Hydrophiloidea). Biol. Skr. 40: 1-368.

Hansen M. 1997: Evolutionary trends in "staphyliniform" beetles (Coleoptera). Steenstrupia 23: 43-86.

HANSKI I. 1987: Nutritional ecology of dung- and carrionfeeding insects. In Slansky Jr. F. \& Rodriguez J.G. (eds): Nutritional Ecology of Insects, Mites, and Spiders. Wiley, New York, pp. 837-884.

HANSKI I. \& CAMBEFORT Y. 1991: The dung insect community. In Hanski I. \& Cambefort Y. (eds): Dung Beetle Ecology. Princeton University Press, Pinceton, New Jersey, pp. 5-21.

HaRdenBerg C.B. 1907: Comparative studies in the trophi of the Scarabaeidae. Trans. Wis. Acad. Sci. Arts Lett. 15: 548-602 (part II).

Hata K. \& Edmonds W.D. 1983: Structure and function of the mandibles of adult dung beetles (Coleoptera: Scarabaeidae). Int. J. Insect Morphol. Embryol. 12: 1-12.

Holter P. 2000: Particle feeding in Aphodius dung beetles (Scarabaeidae): old hypotheses and new experimental evidence. Funct. Ecol. 14: 631-637.

Holter P., Scholtz C.H. \& Wardhaugh K.G. 2002: Dung feeding in adult scarabaeines (tunnellers and endocoprids): even large dung beetles eat small particles. Ecol. Entomol. 27: $169-176$.

Horion A. 1958: Faunistik der Mitteleuropäischen Käfer. Band VI: Lamellicornia (Scarabaeidae - Lucanidae). Aug. Feyel, Überlingen-Bodensee, XXIII + 343 pp.

Krell F.-T. 2000: The fossil record of Mesozoic and Tertiary Scarabaeoidea (Coleoptera: Polyphaga). Invertebr. Taxon. 14: 871-905.

KüHNE R. 1995: Daten zur Biologie ausgewählter GeotrupesArten: G. spiniger Marsham, G. vernalis Linné, und G. stercorosus Scriba (Coleoptera, Scarabaeidae, Geotrupini). Dt. Entomol. Z. 42: 343-367.

LAWrence J.F. \& Newton A.F. 1995: Families and subfamilies of Coleoptera (with selected genera, notes, references and data on family-group names). In Pakaluk J. \& Ślipiński S.A. (eds): Biology, Phylogeny, and Classification of Coleoptera: Papers Celebrating the 80th Birthday of Roy A. Crowson. Muzeum i Instytut Zoologii PAN, Warszawa, pp. 770-1006.

Madle H. 1934: Zur Kenntnis der Morphologie, Ökologie und Physiologie von Aphodius rufipes Lin. und einigen verwandten Arten. Zool. Jb. (Anat. Ontog. Tiere) 58: 303-396.
Miller A. 1961: The mouth parts and digestive tract of adult dung beetles (Coleoptera: Scarabaeidae), with reference to the ingestion of helminth eggs. J. Parasit. 47: 735-744.

Miller A., Chi-Rodriguez E. \& Nichols R.L. 1961: The fate of helminth eggs and protozoan cysts in human feces ingested by dung beetles (Coleoptera: Scarabaeidae). Amer. J. Trop. Med. Hyg. 10: 748-754.

Nel A. \& Scholtz C.H. 1990: Comparative morphology of the mouthparts of adult Scarabaeoidea (Coleoptera). Entomol. Mem. Dep. Agric. Dev. Repub. S. Afr. 80: 1-84.

Palestrini C. \& Zunino M. 1985: Osservazioni sul regime alimentare dell'adulto in alcune specie del genere Thorectes Muls. (Coleoptera, Scarabaeoidea: Geotrupidae). Boll. Mus. Reg. Sci. Nat. Torino 3: 183-190.

Philips T.K., Pretorius E. \& Scholtz C.H. 2004: A phylogenetic analysis of dung beetles (Scarabaeinae: Scarabaeinae): unrolling an evolutionary history. Invertebr. Syst. 18: 53-88.

REMBIAŁKOWSKA E. 1982: Energy balance of the developmental period of Geotrupes stercorosus (Scriba) (Scarabaeidae, Coleoptera). Ekol. Pol. 30: 393-427.

Scholtz C.H. 1990: Phylogenetic trends in the Scarabaeoidea (Coleoptera). J. Nat. Hist. 24: 1027-1066.

Scholtz C.H. 2000: Evolution of flightlessness in Scarabaeoidea (Insecta, Coleoptera). Dt. Entomol. Z. 47: 5-28.

Scholtz C.H. \& Chown S.L. 1995: The evolution of habitat use and diet in the Scarabaeoidea: a phylogenetic approach. In Pakaluk J. \& Ślipiński S.A. (eds): Biology, Phylogeny, and Classification of Coleoptera: Papers Celebrating the 80th Birthday of Roy A. Crowson. Muzeum i Instytut Zoologii PAN, Warszawa, pp. 355-374.

TEICHERT M. 1956: Nahrungsspeicherung von Geotrupes vernalis L. und Geotrupes stercorosus Scriba (Coleopt. Scarab.). Wiss. Z. Martin-Luther-Univ. Halle-Wittenberg (Math.-Nat.) 5: 669-672.

Tyndale-Biscoe M. 1990: Common Dung Beetles in Pastures of Southeastern Australia. CSIRO Australia, Melbourne, 71 pp.

Zunino M. 1984: Analisi sistematica e zoogeografica della sottofamiglia Taurocerastinae Germain (Coleoptera, Scarabaeoidea: Geotrupidae). Boll. Mus. Reg. Sci. Nat. Torino 2: 445-464.

Received March 24, 2004; revised June 4, 2004; accepted June 4, 2004 